\title{
A new testate amoebae species Centropyxis cavitastoma sp. nov. on deposits of volcanic dust from the Aleutian Islands
}

\author{
Anatoly Bobrov \\ Lomonosov Moscow State University, Moscow 119991, Russia
}

| Submitted April 23, 2020| Accepted May 19, 2020|

\begin{abstract}
Summary
A new species of testate amoebae from the genus Centropyxis found in the upper organogenic horizons of the Adak Island (Alaska) coastal soil is described. The new species is similar to Centropyxis plagiostoma but differs by the large ventral invagination and larger size.
\end{abstract}

Key words: Adak Island, Aleutian Islands, Centropyxis cavitastoma sp. nov., testate amoebae

\section{Introduction}

Testate amoebae inhabit almost all types of biotopes - soils, bogs, bottom deposits of freshwater and marine ecosystems (Chardez, 1965). Centropyxis has world-wide distribution and is considered as a cosmopolitan testate amoeba genus. Patterns of geographical distribution of testate amoebae has been discussed in a number of publications (Foissner, 2006; Smith et al., 2008; Beyens and Bobrov, 2016), however the data regarding the genus Centropyxis are extensively compiled only in the works of Decloitre $(1978,1979)$. It seems that some species from the genus Centropyxis have limited geographic distribution. The aim of the study is to describe new species from poorly studied region. Testate amoebae of volcanic arc region, namely the chain Komandorski - the Aleutian Islands, have not been studied, with the exception of the Bear island, belonging to Komandors (Bobrov, 1999).

\section{Material and methods}

Samples were taken on Adak Island (Savinetsky et al., 2012), part of the Central Aleutian Islands (Fig. 1). All Islands of the archipelago are assigned to the Alaskan Marine National Reserve, USA. The region climate is humid and oceanic. Average temperatures range from $0.5^{\circ} \mathrm{C}$ in January to $11^{\circ} \mathrm{C}$ in August. The precipitation level averages about $1670 \mathrm{~mm}$ per year. In Adak there are usually 263 rainy days per year, making it the second amongst the rainiest cities of the United States.

The samples were taken from the beach of the Sweeper-Cove. The coastal terrace is sharply inclined, its surface is large-hummocked, overgrown with wildrye (Elymus sp.). The capacity of loose alluvia does not exceed $50 \mathrm{~cm}$, below it is the rock base itself. Samples were taken from the smoothed edges of the coastal terrace slope, thus including the two upper horizons: $0-1 \mathrm{~cm}$ (undecayed debris

doi:10.21685/1680-0826-2020-14-2-4 


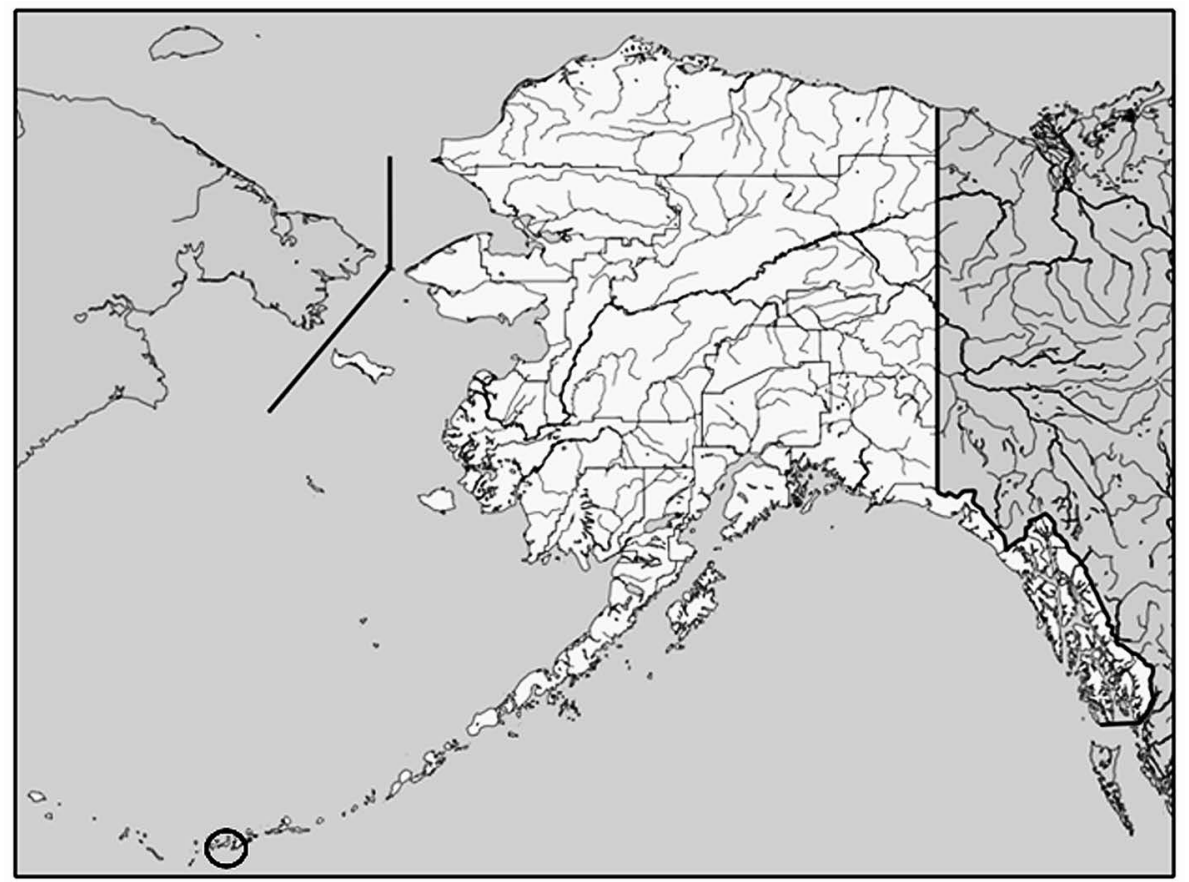

Fig. 1. Adak Island, Aleutian Islands, Alaska, USA.

from last year's cereals), 1-7 cm (turf, densely intertwined with roots, with the predominance of roots over the fine-grained soil, thus the latter is loose, structureless and dark brown).

The samples were placed into plastic containers. In the laboratory, coarse mineral particles and large plant pieces were removed. Then the preliminarily prepared aqueous suspension was passed through a $250 \mu \mathrm{m}$ sieve. Two or three drops of the suspension were analyzed using a Carl Zeiss Axioplan2 microscope with magnifications of $\times 200$ and $\times 400$. Scanning electron microscope (SEM) Jeol 6066 at a voltage of $20 \mathrm{kV}$ was used for a detailed study of the surface structure of the shells. The subjects of morphometric analysis were: 1) shell length, 2) shell width, 3) shell height, 4) apertural depth, 5) apertural width (Figs 2, 3, 4).

\section{Results and discussion}

DesCRIPTION OF CENTROPYXIS CAVITASTOMA SP. NOV.

Description. The shell is circular from the ventral view, rarely wide-oval, flattened in lateral view, with the apertural part slightly more flattened than an opposite part of the shell. Ventral surface is invaginated, forming a vast funnel with a maximum depression in the apertural area. The aperture is located eccentrically, circular or broadly elliptical and is boarded by a crown of large mineral particles. The shell is grey, slightly yellowish. The ventral side is usually smooth and covered by colorless mineral plates of various size and shape. The dorsal side is ornamented with mineral particles of various size, among which there are very large ones, protruding from the general shell contour. The globoid formations of nanometric size are often found on the dorsal side.

Measurements. Shell length 99.71-122.72 $\mu \mathrm{m}$, shell width $84.37-118.89 \mu \mathrm{m}$, apertural length 26.85-39.90 $\mu \mathrm{m}$, apertural breadth 23.01-34.52 $\mu \mathrm{m}$, shell height 48.10-54.60 $\mu \mathrm{m}$ (Table 1; Fig. 2).

Habitat. Soil formed on volcanic deposits, plant community dominated by Elymus sp.

Etymology. The species name cavitastoma derived from the Latin cavitatis (English version - cavity) and analogous to the species name Centropyxis plagiostoma.

Type locality. The type locality of species is surface soil on volcanic deposits under low temperature and high humidity conditions with Elymus sp. dominated on Adak Island, Aleutian archipelago, USA.

Type specimens. Morphometric analyses were based on the holotype specimens of Centropyxis cavitastoma sp. nov., stored at Faculty of Soil Science Moscow State University named by M.V. Lomonosov, Russia (reference 2020-1). 


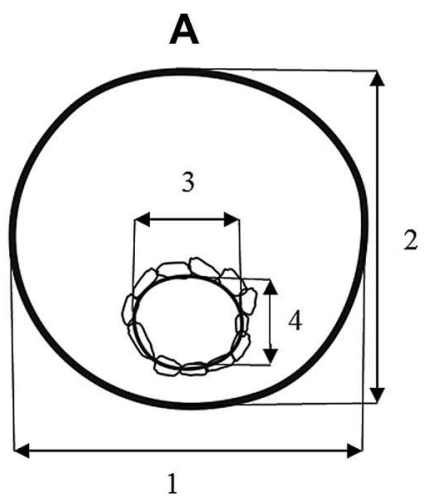

B

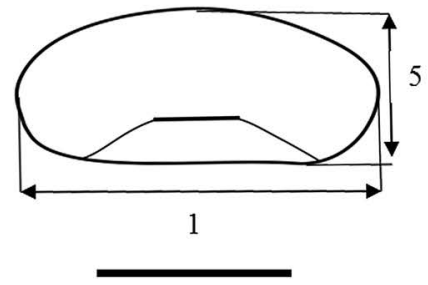

C

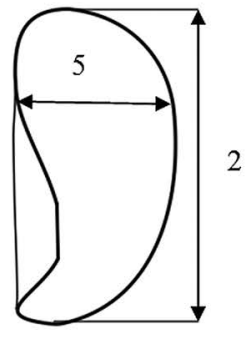

Fig. 2. Outline of Centropyxis cavitastoma sp. nov., in ventral (A) and lateral (B, C) views. 1 - Shell length, 2 - shell width, 3 - apertural length, 4 - apertural breadth 5 - shell height. Scale bar : $60 \mu \mathrm{m}$.
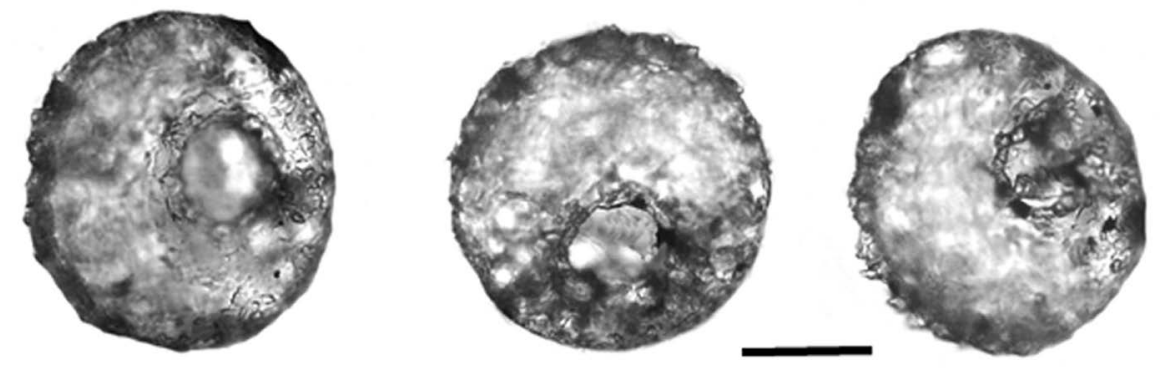

Fig. 3. Light microscopical image of Centropyxis cavitastoma sp. nov. from ventral view. Scale bar $-50 \mu \mathrm{m}$.

List of associated testate amoebae. The species was found in associations with the following species: Arcella arenaria compressa, Trigonopyxis arcula, Centropyxis constricta, C. constricta minor, C. elongata, C. plagiostoma, C. sylvatica, Cyclopyxis eurystoma, C. eurystoma parvula, C. kahli, Plagiopyxis declivis, Heleopera petricola, H. petricola amethystea, $H$. rosea, Nebela lageniformis, N. militaris, N. parvula, N. tincta major, Argynnia vitraea, Valkanovia

Table 1. Morphometric characteristics of Centropyxis cavitastoma sp. nov.

\begin{tabular}{|l|l|l|l|l|l|}
\hline Character & $\begin{array}{c}\text { Shell } \\
\text { length } \\
\mathbf{1}\end{array}$ & $\begin{array}{c}\text { Shell } \\
\text { width } \\
\mathbf{2}\end{array}$ & $\begin{array}{c}\text { Aperture } \\
\text { height } \\
\mathbf{3}\end{array}$ & $\begin{array}{c}\text { Aperture } \\
\text { width } \\
\mathbf{4}\end{array}$ & $\begin{array}{c}\text { Shell } \\
\text { height } \\
\mathbf{5}\end{array}$ \\
\hline $\mathrm{N}$ & 30 & 30 & 30 & 30 & 30 \\
\hline Min & 99.71 & 84.37 & 26.85 & 23.01 & 48.10 \\
\hline Max & 122.72 & 118.89 & 39.90 & 34.52 & 54.60 \\
\hline Mean & 110.60 & 101.94 & 33.60 & 27.38 & 52.38 \\
\hline SD & 5.89 & 8.30 & 3.99 & 3.34 & 1.75 \\
\hline Median & 110.07 & 99.71 & 30.68 & 26.85 & 52.26 \\
\hline CV & 5.32 & 8.14 & 11.87 & 12.22 & 3.34 \\
\hline
\end{tabular}

Notes: SD - standard deviation; CV - coefficient of variation in \%; Min - minimum value; Max - maximum value; Mean - the arithmetic mean, Median - madian, $\mathrm{N}$ - number of individuals investigated; measurements in $\mu \mathrm{m}$. delicatula, V. elegans, Assulina muscorum, A. minuta, Tracheleuglypha acolla, Euglypha laevis, Corythion orbicularis, C. dubium minima, Trinema complanatum, T. galeata.

\section{TAXONOMY}

Arcellinida Kent, 1880

Family Centropyxidae Jung, 1942

Genus Centropyxis Stein, 1857

Centropyxis cavitastoma sp. nov.

\section{COMPARISON WITH SIMILAR SPECIES}

The general outlines of specimens of Centropyxis plagiostoma and Centropyxis cavitastoma sp. nov. are similar. Important differences are observed in the structural peculiarities of the ventral zone. Centropyxis plagiostoma aperture is located on the anterior half of the ventral surface. It is elliptical to almost circular, with an uneven edge often completely or partially covered with large quartz particles ("dents"); distinctly invaginated, pre-oral portion abruptly curved, thus the ventral surface itself is flat (Fig. 4) and gradually inclined (Bonnet and Tho- 
A
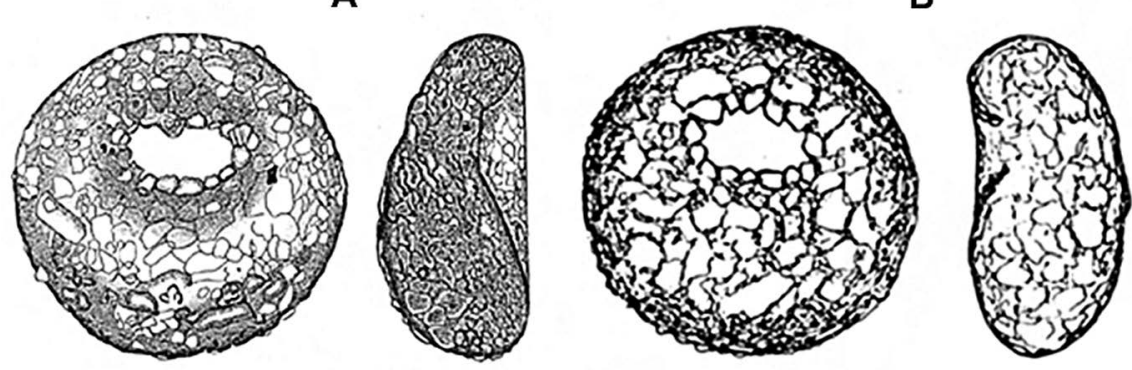

Fig. 4. Centropyxis plagiostoma. A - After Foissner and Korganova, 1995; B - after Bonnet and Thomas, 1955.
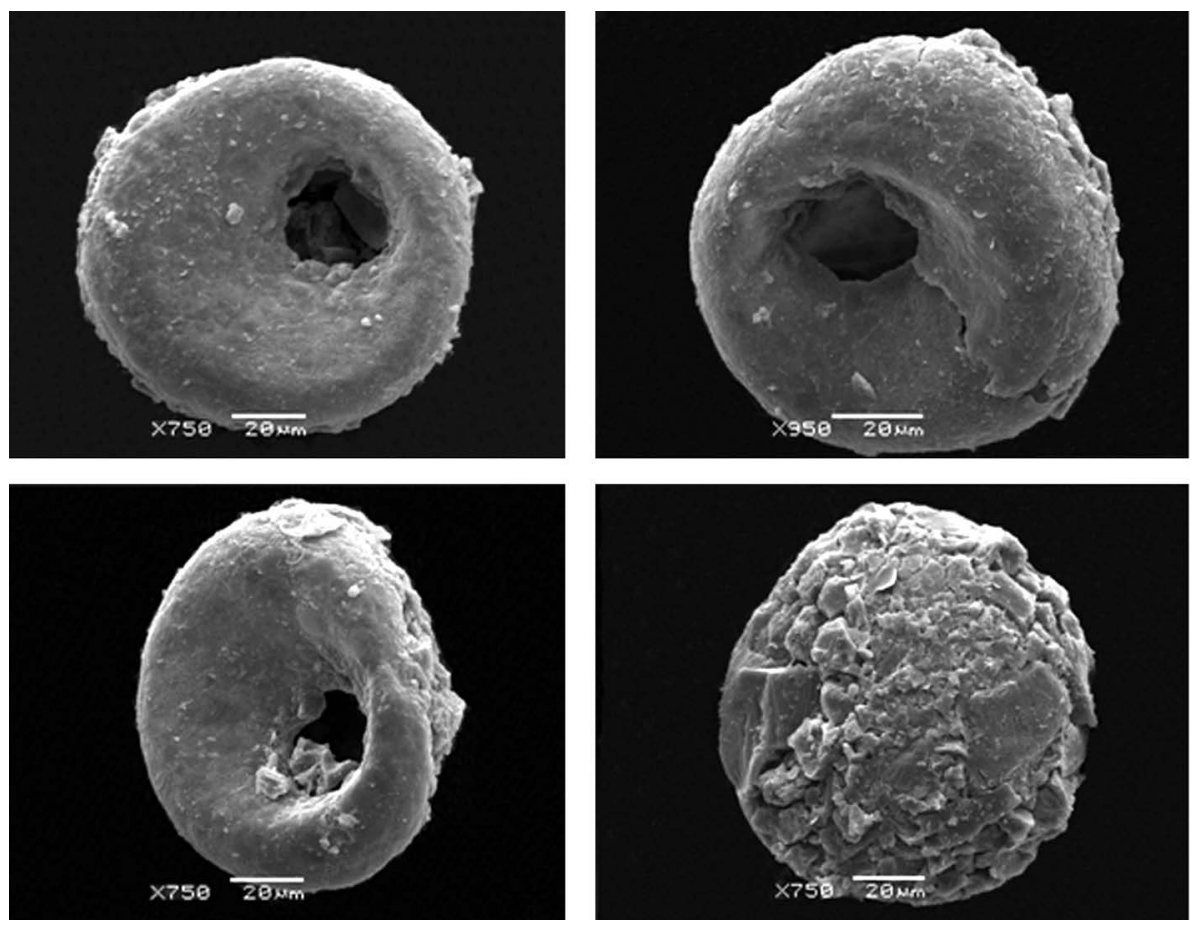

Fig. 5. SEM images of Centropyxis cavitastoma sp. nov.

mas, 1955). In Centropyxis cavitastoma sp. nov. the ventral surface forms a vast funnel with a maximum depth in the apertural area (Fig. 5). Foissner and Korganova (1995) analyzed, as they say Centropyxis plagiostoma, from the upper soil horizon of a deciduous forest of Eastern Caucasus and gave their drawings of the species, which is essentially differs in morphology of the ventral side from presented in the original description (Bonnet and Thomas, 1955). At the same time their drawings much more correspond to morphological characteristics of Centropyxis cavitastoma sp. nov. Thus, we suggest that the species described in the sample from the Caucasus as Centropyxis plagiosoma (Foissner and
Korganova, 1995), according to its morphological characteristics, can be attributed to Centropyxis cavitostoma.

Centropyxis plagiostoma and Centropyxis plagiostoma terricola, inhabit soils and sometimes mosses with near-neutral and slightly alkaline $\mathrm{pH}$ of soil solution (Foissner and Korganova, 1995). Centropyxis plagiostoma oblonga inhabits Sphagnum mosses (Chardez, 1965; Decloitre, 1979). The type habitat of Centropyxis cavitastoma sp. nov. is undeveloped turf from last year's cereals under high humidity conditions.

Shell diameter of Centropyxis plagiostoma is in the range of 56-102 $\mu \mathrm{m}$ (Bonnet and Thomas, 1955; 
Foissner and Korganova, 1995). The dimensions of Centropyxis cavitastoma sp. nov. are much high (Table 1).

\section{Acknowledgements}

I thank D.A. Alexeev for editing the English version of this paper and N.K. Kiseleva, A.B. Savinetsky for providing the samples from Adak Island, Aleutian archipelago, Alaska, USA. This article was prepared with the financial support from the Russian Foundation for Basic Research (project 19-05-50093).

\section{References}

Beyens L. and Bobrov A. 2016. Evidence supporting the concept of a regionalized distribution of testate amoebae in the Arctic. Acta Protozool. 55, 197-209.

Bobrov A. 1999. Ecological and geographical patterns of distribution and ecology of testate amoebae. Doctor of science thesis. Moscow, 341 pp.

Bonnet L. and Thomas R. 1955. Étude sur les Thécamoebiens du sol (I). Soc. D'Hist. Nat. Toulosuse. 90, 411-428.

Chardez D. 1965. Ecolodie generale des Thecamoebiens (Rhizopoda testacea). Bull. Ins. agron. et Stat. Rech. Gembloux. 33, 306-341.
Decloitre L. 1978. Le genre Centropyxis I. Complements à jour au 31 decembre 1974 de la Monographie du genre parve en 1929. Arch. Protistenk. 120, 63-85.

Decloitre L. 1979. Le genre Centropyxis II. Complements à jour au 31. Decembre 1974, de la Monographie du genre parue en 1929. Arch. Protistenk. 121, 162-192.

Foissner W. 2006. Biogeography and dispersal of micro-organisms: a review emphasizing protists. Acta Protozoologica. 45, 111-136.

Foissner W. and Korganova G. A. 1995. Redescription of three testate amoebae (Protozoa, Rhizopoda) from a Caucasian Soil: Centropyxis plagiostoma Bonnet et Thomas, Cyclopyxis kahli (Deflandre) and C. intermedia Kufferath. Arch. Protistenk. 146, 13-28.

Savinetsky A.B., West D.L., Antipushina Zh.A., Khassonov B.F., Kiseleva N.K., Krylovich O.A. and Pereladov A.M. 2012. The reconstruction of ecosystems history of Adak Island (Aleutian Islands) during the Holocene. The People Before. The geology, paleoecology and archaeology of Adak Island, Alaska. BAR International Series 2322, 75-106.

Smith H.G., Bobrov A. and Lara E. 2008. Diversity and biogeography of testate amoebae. Biodiversity and Conservation. 17, 345-363.

Address for correspondence: Anatoly Bobrov. Lomonosov Moscow State University, Leninskie Gory, Moscow, 119991, Russia; e-mail: anatoly-bobrov@yandex.ru 